\title{
Polycomb Protein SUZ12
}

National Cancer Institute

\section{Source}

National Cancer Institute. Polycomb Protein SUZ12. NCI Thesaurus. Code C73547.

Polycomb protein SUZ12 (739 aa, $\sim 83 \mathrm{kDa}$ ) is encoded by the human SUZ12 gene. This protein is a histone methyltransferase and plays a critical role in embryonic development. 